\title{
Soft liquefaction of the red seaweed Grateloupia turuturu Yamada by ultrasound-assisted enzymatic hydrolysis process
}

\author{
Le Guillard Cecile ${ }^{1,2}$, Bergé Jean-Pascal ${ }^{3}$, Donnay-Moreno Claire ${ }^{1}$, Bruzac Sandrine ${ }^{1}$, \\ Ragon Jean-Yves ${ }^{1}$, Baron Regis ${ }^{1}$, Fleurence Joel ${ }^{2}$, Dumay Justine ${ }^{2,{ }^{*}}$
}

1 IFREMER centre de Nantes BP 21105, BIORAFHE, 44311, Nantes cedex 03, France

2 LUNAM Université de Nantes, MMS, Nantes, 2 rue de la Houssinière, BP 92208, 44322, Nantes

cedex 03, France

${ }^{3}$ IDMer, 2 rue Batelière, 56100, Lorient, France

*Corresponding author : Justine Dumay, email address : justine.dumay@univ-nantes.fr

\begin{abstract}
:
Ultrasound-assisted enzymatic hydrolysis is a recent process, increasingly employed for plant biomass liquefaction and the recovery of soluble biomolecules. However, to our knowledge, it has never been used on seaweeds, particularly wet ones. The aim of this study was to compare the efficiency of three processes on the liquefaction of the red seaweed Grateloupia turuturu Yamada: enzyme-assisted extraction (EAE), ultrasound-assisted extraction (UAE), and their combination, ultrasound-assisted enzymatic hydrolysis (UAEH). These comparisons will allow the identification as to which process achieves the highest extraction yield of water-soluble compounds. For this purpose, experiments were conducted at $40^{\circ} \mathrm{C}$ for $6 \mathrm{~h}$ using an enzymatic cocktail of four industrial carbohydrases and an original ultrasonic flow-through reactor. After $6 \mathrm{~h}$, similar profiles were observed between EAE and UAE with the recovery of $71-74 \%$ of the initial material into the soluble phase. However, when these processes were combined, up to $91 \%$ solubilized material was observed in the same time, with a synergistic effect after $2 \mathrm{~h}$. From a biochemical point of view, UAEH improved the extraction of nitrogen and carbon compounds and, more precisely, carbohydrates and amino acids. This study demonstrates that ultrasound improved the enzymatic hydrolysis, probably by an increase in the mass transfer and a disruption of the thallus due to the implosion of the cavitation bubbles generated. UAEH is clearly an efficient procedure for the liquefaction of wet seaweeds, enabling the recovery of valuable components.
\end{abstract}

Keywords : Ultrasound-assisted enzymatic hydrolysis, Enzymatic hydrolysis, Ultrasound, Liquefaction, Algae, Grateloupia turuturu 


\section{Introduction}

Although several seaweeds have been industrially processed for many decades for applications in agriculture, animal feed, food, cosmetics and pharmaceuticals, many remain unexploited. This is the case for the proliferative red seaweed Grateloupia turuturu (Yamada), which was introduced on the Brittany coast in the 1970s and is now abundant on the French Atlantic coast (Munier et al. 2013; Stiger-Pouvreau and Thouzeau 2015). Red seaweeds are interesting due to their richness in a wide range of biomolecules and their worldwide distribution. Indeed, as recently demonstrated, they appear to be a promising feedstock for biorefinery (Baghel et al. 2014; Baghel et al. 2015). This concept of biorefinery involves the development of eco-friendly processes for sequential recovery of molecules (Baghel et al. 2014). Furthermore, novel techniques had demonstrated their interest for the extraction of seaweed biomolecules. Indeed, these novel extraction technologies allow to reduce the use of organic solvents and the treatment time. They are also able to preserve the activity of target compounds and to obtain higher extraction yields with a lower cost in comparison to traditional extraction methods (Kadam et al. 2013; Michalak and Chojnacka 2014; Kadam et al. 2015a). Nevertheless, the main challenge in the development of novel extraction methods is their transfer on an industrial scale (Kadam et al. 2013; Michalak and Chojnacka 2014; Kadam et al. 2015a). Currently, the enzyme-assisted extraction (EAE) and the ultrasound-assisted extraction (UAE) are among the five novel techniques most mentioned in the literature (Kadam et al. 2013; Michalak and Chojnacka 2014; Kadam et al. 2015a). Both processes are described as feasible and efficient alternatives to traditional extraction methods (Kadam et al. 2013) and could be transposed on a large-scale (Kadam et al. 2015a). This study dealing with the extraction's improvement of compounds from G. turuturu; among the three processes investigated here (EAE, UAE and their combination (UAEH)).

EAE has shown its efficiency in seaweed liquefaction, by increasing the digestibility of proteins and enabling the extraction of added-value components such as proteins, bioactive peptides, water-soluble pigments (Rphycoerythrin) and antioxidant compounds (Fleurence et al. 1995; Wang et al. 2010; Wijesinghe and Jeon 2012; Dumay et al. 2013). On vegetable biomass, carbohydrases are generally used, alone or in a cocktail (Sørensen et al. 2005; Sørensen et al. 2007; Cerveró et al. 2010; Mensi et al. 2012). In fact, in spite of their different optima for $\mathrm{pH}$ and temperature, the use of such enzymes in combination may lead to a higher level of hydrolysis than a single enzyme, indicating a synergistic effect (Sørensen et al. 2005; Sørensen et al. 2007; Denis et al. 2009a; Denis et al. 2009b).

In the last decade, UAE has been extensively studied in bioprocessing by using ultrasonic baths (Souza et al. 2013; Lunelli et al. 2014) or ultrasonic probes (Kadam et al. 2015c). However, although the use of ultrasound (US) for extracting natural products from different vegetable biomass has been validated (Vinatoru et al. 1997; Mason et al. 2011), very few studies have been conducted on seaweeds. UAE has been successfully used to improve the determination of major and trace elements in seaweed (DomínguezGonzález et al. 2005), to enhance the extraction of sensitive compounds from brown seaweeds (Kadam et al. 2015c) and to improve the drying process of Ascophyllum nodosum (Kadam et al. 2015b). 
The simultaneous combination of enzymatic hydrolysis and sonication is known as ultrasound-assisted enzymatic hydrolysis (UAEH). This process is relatively new and has been mainly developed to convert vegetable biomass or waste into valuable sugars by enhancing the extraction and the hydrolysis of polysaccharides (Leaes et al. 2013; Lunelli et al. 2014; Liu et al. 2014; Wu et al. 2014). According to Lunelli et al. (2014), the ultrasound irradiation is a promising technology to be used in enzymatic hydrolysis in order to obtain sugars. They even say, as Leaes et al. (2013), that ultrasound act as a tool for process intensification. However, the mechanism of this positive interaction is not yet well understood (DelgadoPovedano and Luque de Castro 2015) and several parameters will be involved, such as the type of ultrasonic device, the frequency and power of the ultrasound, the sonication time, the enzyme, the enzyme-to-substrate ratio, etc. (Subhedar and Gogate 2013; Delgado-Povedano and Luque de Castro 2015). Nevertheless, according to several articles, it could be due to the cavitation phenomenon inducing an increase in the mass transfer, enhancing the substrate accessibility to the enzyme (Figure 1) (Mason et al. 2011; Kwiatkowska et al. 2011; Lunelli et al. 2014). In seaweed, a study demonstrated that the use of ultrasound energy could improve the enzymatic hydrolysis for extracting metallic elements by a 12-fold reduction of the process (Peña-Farfal et al. 2005). A recent study put forward the interest of ultrasound to produce bioethanol from Ulva rigida, using an ultrasound assisted saccharification and fermentation process (Korzen et al. 2015).

The aim of the present work was to study the efficiency of a UAEH system on the liquefaction of the wet red seaweed Grateloupia turuturu, in order to intensify the extraction of seaweeds biomolecules. For this purpose, an enzymatic cocktail composed of 4 industrial carbohydrases developed for terrestrial biomass and an original ultrasonic flow-through reactor were used. To the best of our knowledge, this is the first time such an original approach has been proposed.

\section{Materials and methods}

\section{1 Materials}

Seaweed, G. turuturu, was harvested on $24^{\text {th }}$ May 2013, in the intertidal zone of Batz-sur-Mer on the Atlantic coast, France. Epiphytes were removed by hand and algae were partially dewatered with a spin-dryer, then vacuum-packed (Boulanger INV 40, France) and immediately frozen. The algae were stored at $-20^{\circ} \mathrm{C}$ in darkness. Four industrial carbohydrases were selected and combined according to their similar $\mathrm{pH}$ and temperature optima and their complementarity (Table 1). Regarding our target, all of those enzymes do not work at temperatures higher than $40{ }^{\circ} \mathrm{C}$. The resulting enzymatic cocktail was thus composed of 4 enzymes: Sumizyme TG and Sumizyme MC produced by SHIN NIHON CHEMICAL (Japan) and kindly provided by Takabio (France); Multifect ${ }^{\circledR}$ CX 15 L kindly provided by DuPont ${ }^{\mathrm{TM}}$ (United States); and Ultraflo ${ }^{\circledR}$ XL kindly provided by Novozymes ${ }^{\circledR}$ (Denmark).

\section{2 Extraction methods}

A portion of the frozen seaweed was partially defrosted and cut into small pieces (about $5-7 \mathrm{~mm}^{2}$ ) using a 
cutting mill (Microcut Stephan MC 15, Germany). These were subsequently frozen again and stored at $20{ }^{\circ} \mathrm{C}$. All the experiments were performed, at $40 \pm 1{ }^{\circ} \mathrm{C}$, in a jacketed glass reactor vessel $(5 \mathrm{~L})$ containing around $3 \mathrm{~kg}$ of reaction mixture, composed of $20 \%$ wet and cut seaweed homogenized in tap water (corresponding to minimal water quantity to obtain an effective circulation of the reaction mixture, occurred with the pump, in our conditions) with the $\mathrm{pH}$ adjusted to 5.5 by addition of $6 \mathrm{M} \mathrm{HCl}$ (Radiometer analytical TitraLab $^{\circledR}$ 854, France). Homogenization was conducted continuously, at 100 rpm, (Stuart ${ }^{\circledR}$ Overhead Stirrer SS20, Bibby Scientific Ltd, United Kingdom) using a peristaltic pump (Leroy ${ }^{\circledR}$-Somer, France) at a flow rate


control and adjust the temperature in the reactor during the $6 \mathrm{~h}$ of the process (Figure 2a). The temperature inside the reactor and at the outlet of the ultrasonic apparatus was measured and $\mathrm{pH}$ was monitored inside the reactor.

Regular sampling ( $\pm 30 \mathrm{~mL}$; at the beginning of the experiment and after every $30 \mathrm{~min}$ during the first hour, followed by one every hour), was carried out throughout the experiment. Samples were immediately centrifuged (15,500 g, $30 \mathrm{~min}, 20^{\circ} \mathrm{C}$, Beckman Coulter Avanti ${ }^{\circledR} \mathrm{J}$-E Centrifuge, France) providing supernatant and pellet fractions that were weighed and then freeze-dried.

\section{2. 1 Enzyme-assisted extraction (EAE)}

Enzymatic hydrolysis was initiated by the addition of the enzymatic cocktail and monitored during 360 min. After preliminary tests (data not shown), $1 \% \mathrm{w} / \mathrm{w}$ of each enzyme related to the weight of wet seaweed was added, corresponding to a concentration of $0.2 \% \mathrm{w} / \mathrm{w}$ of each enzyme in the reaction mixture. Hydrolysis was carried out at $40 \pm 1{ }^{\circ} \mathrm{C}$, while the ultrasonic reactor was turned off.

\section{2. 2 Ultrasound-assisted extraction (UAE)}

The reaction mixture was sonicated for $6 \mathrm{~h}$ using an ultrasonic flow-through reactor (SONITUBE ${ }^{\circledR} 35 \mathrm{kHz}$, 200 to $400 \mathrm{~W}$ ), manufactured and kindly provided by SYNETUDE (France) (Figure 2b). The SONITUBE ${ }^{\circledR}$ was set to $400 \mathrm{~W}$, the power indicated by the generator varied between 350 and $400 \mathrm{~W}$. So, taken into account the energy efficiency of the device (in order of $85 \%$ ) (Personal communication SYNETUDE), the power really delivered during the experiments in the reaction mixture varied between $300 \mathrm{~W}$ and $340 \mathrm{~W}$. No enzyme was added during these experiments.

\section{2. 3 Ultrasound-assisted enzymatic hydrolysis (UAEH)}

The UAEH process is a combination of the EAE and UAE extraction methods; the US was applied at the same power than for the UAE and the enzymes were added at the same concentration than for the EAE. The experiments were carried out at $40 \pm 1{ }^{\circ} \mathrm{C}$ during $6 \mathrm{~h}$.

\section{3 Analyses}

To identify the biochemical composition of G. turuturu, a portion of the frozen seaweed was freeze-dried and ground in liquid nitrogen, before being stored at $-20^{\circ} \mathrm{C}$. 


\subsection{Dry weight content}

The dry weight of samples was determined gravimetrically, on $10 \mathrm{~g}$ (wet seaweed), after $24 \mathrm{~h}$ at $105^{\circ} \mathrm{C}$. Results are expressed as a percentage of wet seaweed.

\section{3. 2 Ash content}

Total ash content was determined by incineration of $1 \mathrm{~g}$ of seaweed powder in an oven at $550{ }^{\circ} \mathrm{C}$ overnight (Furnace 62700, Barnstead Thermolyne, United States). The ash content is expressed as a percentage of dry seaweed.

\section{3. 3 Determination of the seaweed liquefaction}

For all experiments, the liquefaction of material was calculated over time. The proportion of soluble material was obtained by calculating the ratio between the weight of freeze-dried supernatant $\left(m_{l}\right)$ and the sum of freeze-dried supernatant $\left(m_{1}\right)$ and pellet $\left(m_{2}\right)$, expressed in percentage, according to the equation:

$$
\frac{m_{1}}{\left(m_{1}+m_{2}\right)} \times 100
$$

Thus, for each time, the gain in liquefaction was calculated as the proportion of soluble material without the proportion of soluble material at the beginning of the process.

\section{3. 4 Sodium chloride content $(\mathrm{NaCl})$}

The total sodium chloride content was based on the determination of chloride anions by argentometry using an automatic chloride analyzer (Chloride analyzer Model 926, Sherwood Scientific Ltd, United Kingdom). Prior to analyses, samples of seaweed powder $(2 \mathrm{~g})$ were diluted in $150 \mathrm{ml}$ of MilliQ water and ground using an Ultra Turrax (Ultra Turrax ${ }^{\circledR}$ IKA T18 B, IKA ${ }^{\circledR}$, Germany). The solution was brought to boil for 10 min, homogenized, and filtered on glass wool. The volume was adjusted with ultrapure water to obtain a final volume of $200 \mathrm{~mL}$. Measurements were made using the chloride analyzer after calibration with a $\mathrm{NaCl}$ standard solution at $\mathrm{Cl} 200 \mathrm{mg} . \mathrm{L}^{-1}$. Results are expressed as a percentage.

\section{3. 5 Soluble carbohydrates content}

The water-soluble carbohydrates were analyzed using a phenol-sulfuric acid method (Chaplin 1986). Glucose was used as a standard (range from 15 to $150 \mathrm{mg} . \mathrm{L}^{-1}$ ). Absorbance was measured at $490 \mathrm{~nm}$ (Shimadzu UV-1800, UV-VIS Spectrophotometer, Japan).

\section{3. 6 Elemental composition: carbon and nitrogen}

The elemental $\mathrm{C}$ and $\mathrm{N}$ composition was determined on dehydrated samples (algal powder and freeze-dried supernatants), weighed (1.5-5 mg) and placed in small tin capsules that were carbonized by flash combustion at $1,800{ }^{\circ} \mathrm{C}$. The $\mathrm{C}$ and $\mathrm{N}$ contents were oxidized and converted into a gaseous form, at $950{ }^{\circ} \mathrm{C}$ in a combustion column and at $750{ }^{\circ} \mathrm{C}$ in a reduction column. The gases formed were transferred by carrier gas (helium) and analyzed by gas chromatography (FLASH 2000 NC Organic Elemental Analyzer - Thermo Scientific, United States). Results were integrated using the Eager Xperience for Flash software. 


\section{3. 7 Lipid content}

Total lipid content of G. turuturu was determined gravimetrically according to the Folch method (Folch et al. 1957).

\section{3. 8 Total amino acid (AA) content}

The total amino acid content was determined on selected freeze-dried supernatants, according to $\mathrm{EC} \mathrm{n}^{\circ}$ 152/2009 (2009).

\section{3. 9 Microscopic observations}

Microscopic observations of samples were made before centrifugation in order to estimate and compare the thalli degradation over time. A light microscope with a digital camera (EVOS ${ }^{\circledR}$ XL Core Cell Imaging System, United States) was used, without staining. Two magnifications were performed on the samples: $\mathrm{x}$ 100 and $\mathrm{x} 1,000$.

\section{3. 10 Statistical analysis}

All the extraction processes were made in triplicate $(n=3)$. Means and standard deviation are given for each experiment. Analyses were performed using the software Sigmastat 3.1. Multiple comparison tests were carried out using the Holm-Sidak test following the ANOVA procedure $(\mathrm{p}<0.05)$.

\section{Results and Discussion}

\section{1 Biochemical composition of the seaweed G. turuturu}

The biochemical composition of G. turuturu is presented in Table 2. The dry weight (dw) content observed here (14.2\%) was higher than previous observations of $6.5 \%$ (Munier et al. 2013) and $9.5 \%$ (Denis et al. 2010). This was also the case regarding the mineral content, $30.7 \% \mathrm{dw}$ compared to $15.6 \% \mathrm{dw}$ (Munier et al. 2013) and $18.5 \%$ dw (Denis et al. 2010). These higher values could be explained by the absence of a rinsing step (with tap or distilled water) here, allowing superficial material, particularly salt, to be conserved. This hypothesis is confirmed by the high content of $\mathrm{NaCl}$ found here, representing half of the total mineral content. We decided to not rinse the seaweeds in order to avoid the loss of seaweed compounds (in particular polysaccharides and proteins) (Marrion et al. 2003; Miller 2005) and to save time and money. However, the only washing step not allows to explain the higher amount of minerals found in our work. Indeed, for the same location, year and month of collection, a study demonstrated a mineral content of $35.3 \%$ for a dry weight of $9.7 \%$ (Munier 2013). According to authors, this higher mineral content could be due to the effect of environmental parameters (particularly the sunshine duration) on the biochemical composition of $G$. turuturu.

Lipid content was similar to that previously found (3.7 \% dw) (Kendel et al. 2013). Regarding the amino acid content $(18.4 \% \mathrm{dw})$, as the extraction and analysis procedures greatly differ from the only previously published work on this seaweed (Arasaki and Mino 1973), a comparison is inappropriate. 
Based on the methodology proposed by Lourenço et al. (2002), the nitrogen-to-protein conversion factor was calculated by the ratio of amino acid residues to total nitrogen. As indicated by these authors, due to the strong species variability, a specific conversion factor needs to be calculated in order to estimate the protein content precisely. The conversion factor for G. turuturu was estimated for the first time and found to be 5.09.

\section{2 Comparison of EAE, UAE and UAEH liquefaction}

As expected, the soluble content increased with time (Figure 3). However, without any treatment, the liquefaction level of the seaweed after $6 \mathrm{~h}$ was found to be very low $(8 \pm 1 \%$ increase). Differences were observed regarding the kinetics of liquefaction according to the process used. A noticeable effect of EAE was observed as, despite a lag phase of one hour, a regular increase in soluble material occurred throughout the experiment. This was previously observed when carbohydrases were used to degrade the thallus of $G$. turuturu leading to an increase in reducing sugars in the soluble phase (Denis et al. 2009a; Denis et al. 2009b). Such higher liquefaction was also noticed when UAE was applied but without any lag phase. However, after $6 \mathrm{~h}$ (Figure 4) percentages of solubilized material obtained for EAE (71 $\pm 1 \%$ ) and UAE (74 $\pm 1 \%$ ) were very close, despite a significant difference. When both processes were applied simultaneously (UAEH), the level of liquefaction increased rapidly during the first $3 \mathrm{~h}$, moderately one more hour, and then followed by a stationary phase until the end of the experiment ( $40 \pm 1 \%$ increase) (Figure 3$)$. At the end, up to $91 \pm 0.1 \%$ of the initial dry matter was recovered in the soluble phase (Figure 4$)$. These results indicate that all the processes used were more effective for seaweed liquefaction than autolysis $(\mathrm{p}<0.05)$.

The positive effect of US on the increased soluble fraction is well known and recognized as a valuable solution for recovering plant molecules (Vinatoru et al. 1997; Mason et al. 2011). However, such an effect has only recently been confirmed in seaweeds (Kadam et al. 2015c). Concerning the simultaneous application of enzyme(s) and ultrasound, association benefits have been demonstrated for the extraction of plant compounds (Yachmenev et al. 2009; Leaes et al. 2013; Liu et al. 2014). In the last few years, despite some studies carried out on the understanding of this positive association, the mechanisms involved have not been elucidated yet. Thus, on a model substrate, some works have demonstrated that the enzymatic activity of carbohydrases was increased in presence of ultrasound (Barton et al. 1996; Sulaiman et al. 2010; Souza et al. 2013). One of the most likely mechanisms would be an increased efficiency of mixing and diffusion of reaction components (enzyme(s), substrate(s) and product(s) of the reaction) (Barton et al. 1996). According to Bashari et al. (2013), the increased activity could be also due to the improvement of the enzymes stability, which would be induced by some structural transformations (secondary structure) of their active site. Conversely, a reduction of a commercial cellulase activity has also been shown after the sonication of the enzyme. However, when the cellulase was simultaneously used in presence of its substrate and ultrasound, its activity was higher with US than without it. The authors concluded that, with a simultaneous sonication, the increased interactions and transfers between enzymes and substrate has overcome the undesirable effect of ultrasound on this cellulase (Szabó and Csiszár 2013). In some cases, a synergistic effect between enzymes and US was mentioned (Easson et al. 2011; Wu et al. 2014). Such synergy can be observed here, particularly 
at $2 \mathrm{~h}$ when the sum of liquefaction gain for UAE and EAE (24\%) was lower than that for UAEH (31\%). As previously mentioned, UAEH can also reduce the processing time (Liu et al. 2014) as the maximum liquefaction level here was obtained after $4 \mathrm{~h}$.

To conclude, it seems clear that each case is individual, depending on the type of enzyme, the parameters of hydrolysis and the parameters of sonication (Özbek and Ülgen 2000; Szabó and Csiszár 2013).

\section{3 Biochemical analyses of EAE, UAE, UAEH soluble fractions}

\section{3. 1 Carbohydrate, $C$ and $N$ extraction yields}

In order identify and quantify the dry matter content, some biochemical analyses were carried out on the resulting soluble fractions. To ensure the accuracy of our values, enzymatic cocktail carbohydrates were estimated at $427.43 \mathrm{mg}$ of carbohydrate per $\mathrm{g}$ of enzymatic cocktail. This is in accordance with data provided by the suppliers as: Sumizyme TG contains $50 \%$ dextrins, Sumizyme MC is composed by $79 \%$ maltodextrins and Ultraflo ${ }^{\circledR}$ XL by $30 \%$ glycerol and $20 \%$ sorbitol. No data were communicated for Multifect ${ }^{\circledR}$ CX 15L. In order to avoid an overestimation, these amounts were compared to dried seaweed, giving an overall value of $127.41 \mathrm{mg}$ of carbohydrate per $\mathrm{g}$ of dried seaweed. This was removed from the biochemical composition of soluble fractions for the EAE and UAEH processes. The biochemical compositions of the resulting fractions obtained after $6 \mathrm{~h}$ of treatment are presented in Figure 5.

Compared to the control, carbohydrate extraction was not improved by enzyme addition (EAE), with $133 \pm 5$ $\mathrm{mg} \cdot \mathrm{g}^{-1}$ and $150 \pm 10 \mathrm{mg} \cdot \mathrm{g}^{-1}$, respectively (Figure 5a). This could be due to the low temperature used $\left(40{ }^{\circ} \mathrm{C}\right.$ ), below the optimum for these carbohydrases (Table 1). This temperature was chosen in order to preserve heatsensitive molecules found in red seaweed, such as the R-phycoerythrin (R-PE) which is a red-purple pigment stable up to $40{ }^{\circ} \mathrm{C}$ (Munier et al. 2014). When ultrasound was used (UAE and UAEH), the recovery of carbohydrates into the soluble phases was significantly increased (296 \pm 37 and $439 \pm 16$ mg.g ${ }^{-1}$, respectively), in comparison to the control. Thus, as previously noticed, US may have improved the enzyme activity leading to higher levels of polysaccharide extraction (Yachmenev et al. 2009; Leaes et al. 2013; Lunelli et al. 2014; Liu et al. 2014). Indeed, ultrasound allow the polysaccharides degradation inducing a reduction of viscosity and a decrease of the polysaccharide molecular weights (Petit et al. 2007; Pétrier et al. 2008; Zhou et al. 2008). Moreover, the ultrasonic depolymerisation could facilitate the access of carbohydrases to their substrate, which would further increase the cell wall polysaccharides degradation. This could explain why the highest level of carbohydrates found was observed in the soluble fractions obtained by the combined process (UAEH).

Whatever the process used, the extraction of carbon and nitrogen was enhanced compared to the control (Figure 5b and Figure 5c). For both $\mathrm{C}$ and N, UAEH was the most efficient leading to an extraction yield of $92 \pm 0.3 \%$ of the initial carbon and $74 \pm 1.2 \%$ of the initial nitrogen. Despite some discrepancies, no statistical differences $(\mathrm{p}<0.05)$ were observed between the $\mathrm{C}$ and $\mathrm{N}$ contents of soluble fractions recovered after $6 \mathrm{~h}$ for EAE and UAE treatments. This is in accordance with the similarity of their dry matter content 
(Figure 4). Although a direct link can be established between nitrogen and proteins, this is more complex for carbon, which is found in both proteins and carbohydrates. For nitrogen, it can be assume that the polysaccharides degradation by UAEH increases the release of nitrogenous compounds and thus proteins.

\section{3. 2 Amino acids (AA) analysis}

As is commonly known, AA content is the best measurement of proteins in plant tissue (Khanizadeh et al. 1995) thus the composition of the UAEH fraction obtained after $6 \mathrm{~h}$ was established (Figure 6).

For all samples (raw material, control and UAEH), about 17 amino acids were detected including 8 essential ones (EAA). As expected, aspartic acid (Asp) and glutamic acid (Glu) were the most abundant as they occur at high levels in seaweeds, particularly red seaweeds (Galland-Irmouli et al. 1999; Wong and Cheung 2000; Diniz et al. 2011). In contrast, histidine (His), cysteine (Cys) and methionine (Met) were found in low proportions. Regarding the ratio of EAA/total amino acids, some discrepancies were observed. In the raw material, this ratio was $38 \%$, close to that found in the seaweed of the same class, Palmaria palmata, and confirming their nutritional value (Galland-Irmouli et al. 1999). For both control and UAEH samples, this ratio decreased to $34 \%$ indicating a modification in the overall amino acid composition of extracted proteins. In fact, extracts (control and UAEH) were enriched in cysteine (Cys), aspartic acid (Asp), alanine (Ala), glutamic acid (Glu), glycine (Gly) and serine (Ser) while they contained less histidine (His), leucine (Leu), phenylalanine (Phe), arginine (Arg) and tyrosine (Tyr) compared to the raw material. Moreover, some differences were observed between the control and the UAEH. For example, compared to the control, UAEH enhanced the proportion of isoleucine (Ile), threonine (Thr), valine (Val), aspartic acid (Asp), and glutamic acid (Glu); while leucine (Leu), lysine (Lys), phenylalanine (Phe), arginine (Arg) and tyrosine (Tyr) were less abundant. As previously depicted, more of nitrogenous compounds were extracted with the UAEH compared to the control (Figure 5c). It can be assumed that some proteins could be solubilized thanks to the $\mathrm{UAEH}$; and these proteins would have some differences concerning their amino acids profiles. Hence, the differences between amino acids profiles could be explained. Indeed, processes investigated here, especially UAEH, could enhance the total protein extraction, resulting in a de facto modification of the amino acid relative composition. To our knowledge, there are only few studies mentioning ultrasound for the extraction of amino acids. Thus, recently the interest of ultrasound (UAE) was demonstrated in comparison to conventional methods to extract amino acids from grapes (Carrera et al. 2015) and taurine (free amino acid) from Porphyra yezoensis (Wang et al. 2015). Carrera et al. (2015) found that the level of individual amino acids in the extracts were always higher using ultrasound rather than their conventional method (maceration), with higher recoveries for most amino acids. Moreover, the simultaneous use of ultrasound and enzyme has demonstrated its effectiveness, on seaweeds, for the extraction of iodinated amino acids (Romarís-Hortas et al. 2013).

\section{4 Microscopic observations}

In order to visualize the effect of the different processes, some microscopic observations were made (Figure 7). After 3 and $6 \mathrm{~h}$, for all treatments (EAE, UAE and UAEH), cell wall disruption was noticed, confirmed 
by the observation of cellular debris. Such an effect of EAE has been previously observed, representing the enzymatic degradation of the thallus over time (Denis et al. 2009a). UAE seemed to be even more disruptive as more holes were observed, confirming previous works on plants (Toma et al. 2001; Easson et al. 2011). However, of the 3 procedures used here, the most disruptive one was the combination of US and enzymes. Sonication led to the creation of cavitation bubbles, which may have imploded leading to the deterioration of the seaweed surface, the breakdown of the parietal cell wall and the improved penetration of enzymes into the substrate (Toma et al. 2001; Mason et al. 2011).

\section{Conclusions}

Three procedures for liquefying the red seaweed Grateloupia turuturu, in order to maximize the solubility of the components in $6 \mathrm{~h}$, were compared. Among these, the combination of non-specific carbohydrases and ultrasound was found to be the most efficient in terms of: liquefaction level (x 1.7 compared to the control), extraction of carbohydrates (x 3.3), nitrogen (x 1.8), carbon (x 2.2) and amino acids (x 2.1) (Table 3). Moreover, the kinetics of liquefaction revealed that a synergistic effect occurred after $2 \mathrm{~h}$ of treatment. Further biochemical analysis could be interesting such as the polysaccharides molecular weight determination before and after UAEH and the identification of simple sugars in soluble fractions generated. Although such an approach has been successfully conducted on different substrates in recent years, this is, to the best of our knowledge, the first time that it has been carried out on seaweed, furthermore on a fresh one. It could be interesting to test this UAEH process on other red seaweeds, in order to evaluate its transfer feasibility to others species. The original ultrasonic system used here can easily be scaled up but, before an industrial application, further work must be done, notably to study the temperature effect, the nature of the enzyme, the ultrasonic power and the time of processing. 


\section{References}

Arasaki T, Mino N (1973) The Alkali Soluble Proteins in Marine Algae. Eiyo Shokuryo 26:129-133. doi: $10.4327 /$ jsnfs 1949.26 .129

Baghel RS, Reddy CRK, Jha B (2014) Characterization of agarophytic seaweeds from the biorefinery context. Bioresour Technol 159:280-285. doi: 10.1016/j.biortech.2014.02.083

Baghel RS, Trivedi N, Gupta V, et al (2015) Biorefining of marine macroalgal biomass for production of biofuel and commodity chemicals. Green Chem. doi: 10.1039/C4GC02532F

Barton S, Bullock C, Weir D (1996) The effects of ultrasound on the activities of some glycosidase enzymes of industrial importance. Enzyme Microb Technol 18:190-194. doi: 10.1016/0141-0229(95)00092-5

Bashari M, Eibaid A, Wang J, et al (2013) Influence of low ultrasound intensity on the degradation of dextran catalyzed by dextranase. Ultrason Sonochem 20:155-161. doi: 10.1016/j.ultsonch.2012.06.010

Carrera C, Ruiz-Rodríguez A, Palma M, Barroso CG (2015) Ultrasound-assisted extraction of amino acids from grapes. Ultrason Sonochem 22:499-505. doi: 10.1016/j.ultsonch.2014.05.021

Cerveró JM, Skovgaard PA, Felby C, et al (2010) Enzymatic hydrolysis and fermentation of palm kernel press cake for production of bioethanol. Enzyme Microb Technol 46:177-184. doi:

10.1016/j.enzmictec.2009.10.012

Chaplin MF (1986) Monosaccharides. In: Chaplin MF, Kennedy JF (eds) Carbohydrate analysis: a practical approach, First. IRL Press, Oxford, pp 1-36

Delgado-Povedano MM, Luque de Castro MD (2015) A review on enzyme and ultrasound: A controversial but fruitful relationship. Anal Chim Acta. doi: 10.1016/j.aca.2015.05.004

Denis C, Le Jeune H, Gaudin P, Fleurence J (2009a) An evaluation of methods for quantifying the enzymatic degradation of red seaweed Grateloupia turuturu. J Appl Phycol 21:153-159. doi: 10.1007/s10811008-9344-2

Denis C, Morançais M, Gaudin P, Fleurence J (2009b) Effect of enzymatic digestion on thallus degradation and extraction of hydrosoluble compounds from Grateloupia turuturu. Bot Mar 52:262-267. doi: 10.1515/BOT.2009.035

Denis C, Morançais M, Li M, et al (2010) Study of the chemical composition of edible red macroalgae Grateloupia turuturu from Brittany (France). Food Chem 119:913-917. doi:

10.1016/j.foodchem.2009.07.047

Diniz GS, Barbarino E, Oiano-Neto, et al (2011) Gross Chemical Profile and Calculation of Nitrogen-toProtein Conversion Factors for Five Tropical Seaweeds. Am J Plant Sci 02:287-296. doi: 10.4236/ajps.2011.23032

Domínguez-González R, Moreda-Piñeiro A, Bermejo-Barrera A, Bermejo-Barrera P (2005) Application of ultrasound-assisted acid leaching procedures for major and trace elements determination in edible seaweed by inductively coupled plasma-optical emission spectrometry. Talanta 66:937-942. doi: 10.1016/j.talanta.2004.12.051

Dumay J, Clément N, Morançais M, Fleurence J (2013) Optimization of hydrolysis conditions of Palmaria palmata to enhance R-phycoerythrin extraction. Bioresour Technol 131:21-27. doi: 10.1016/j.biortech.2012.12.146

Easson MW, Condon B, Dien BS, et al (2011) The application of ultrasound in the enzymatic hydrolysis of switchgrass. Appl Biochem Biotechnol 165:1322-1331. doi: 10.1007/s12010-011-9349-1 
EC n ${ }^{\circ} 152 / 2009$ (2009) In: Official Journal of the European Union. http://eurlex.

europa.eu/LexUriServ/LexUriServ.do?uri=OJ:L:2009:054:0001:0130:EN:PDF. Accessed 26 January 2015

Fleurence J, Massiani L, Guyader O, Mabeau S (1995) Use of enzymatic cell wall degradation for improvement of protein extraction from Chondrus crispus, Gracilaria verrucosa and Palmaria palmata. J Appl Phycol 7:393-397. doi: 10.1007/BF00003796

Folch J, Lees M, Sloane Stanley GH (1957) A simple method for the isolation and purification of total lipides from animal tissues. J Biol Chem 226:497-509.

Galland-Irmouli A-V, Fleurence J, Lamghari R, et al (1999) Nutritional value of proteins from edible seaweed Palmaria palmata (dulse). J Nutr Biochem 10:353-359. doi: 10.1016/S09552863(99)00014-5

Kadam SU, Álvarez C, Tiwari BK, O’Donnell CP (2015a) Chapter 9 - Extraction of biomolecules from seaweeds. In: Troy BKTJ (ed) Seaweed Sustainability. Academic Press, San Diego, pp 243-269

Kadam SU, Tiwari BK, O’Donnell CP (2013) Application of novel extraction technologies for bioactives from marine algae. J Agric Food Chem 61:4667-4675. doi: 10.1021/jf400819p

Kadam SU, Tiwari BK, O'Donnell CP (2015b) Effect of ultrasound pre-treatment on the drying kinetics of brown seaweed Ascophyllum nodosum. Ultrason Sonochem 23:302-307. doi:

10.1016/j.ultsonch.2014.10.001

Kadam SU, Tiwari BK, Smyth TJ, O'Donnell CP (2015c) Optimization of ultrasound assisted extraction of bioactive components from brown seaweed Ascophyllum nodosum using response surface methodology. Ultrason Sonochem 23:308-316. doi: 10.1016/j.ultsonch.2014.10.007

Kendel M, Couzinet-Mossion A, Viau M, et al (2013) Seasonal composition of lipids, fatty acids, and sterols in the edible red alga Grateloupia turuturu. J Appl Phycol 25:425-432. doi: 10.1007/s10811-0129876-3

Khanizadeh S, Buszard D, Zarkadas CG (1995) Misuse of the Kjeldahl method for estimating protein content in plant tissue. Hortscience 30:1341-1342.

Korzen L, Pulidindi IN, Israel A, et al (2015) Single step production of bioethanol from the seaweed Ulva rigida using sonication. RSC Adv 5:16223-16229. doi: 10.1039/C4RA14880K

Kwiatkowska B, Bennett J, Akunna J, et al (2011) Stimulation of bioprocesses by ultrasound. Biotechnol Adv 29:768-780. doi: 10.1016/j.biotechadv.2011.06.005

Leaes EX, Zimmermann E, Souza M, et al (2013) Ultrasound-assisted enzymatic hydrolysis of cassava waste to obtain fermentable sugars. Biosyst Eng 115:1-6. doi: 10.1016/j.biosystemseng.2013.02.001

Liu Y, Gong G, Zhang J, et al (2014) Response surface optimization of ultrasound-assisted enzymatic extraction polysaccharides from Lycium barbarum. Carbohydr Polym 110:278-284. doi: 10.1016/j.carbpol.2014.03.040

Lourenço SO, Barbarino E, De-Paula JC, et al (2002) Amino acid composition, protein content and calculation of nitrogen-to-protein conversion factors for 19 tropical seaweeds. Phycol Res 50:233241. doi: $10.1046 / \mathrm{j} .1440-1835.2002 .00278 . x$

Lunelli FC, Sfalcin P, Souza M, et al (2014) Ultrasound-assisted enzymatic hydrolysis of sugarcane bagasse for the production of fermentable sugars. Biosyst Eng 124:24-28. doi:

10.1016/j.biosystemseng.2014.06.004

Marrion O, Schwertz A, Fleurence J, et al (2003) Improvement of the digestibility of the proteins of the red alga Palmaria palmata by physical processes and fermentation. Food Nahr 47:339-344. doi: 


\subsection{2/food.200390078}

Mason TJ, Chemat F, Vinatoru M (2011) The Extraction of Natural Products using Ultrasound or Microwaves. Curr Org Chem 15:237-247. doi: 10.2174/138527211793979871

Mensi F, Ksouri J, Seale E, et al (2012) A statistical approach for optimization of R-phycoerythrin extraction from the red algae Gracilaria verrucosa by enzymatic hydrolysis using central composite design and desirability function. J Appl Phycol 24:915-926. doi: 10.1007/s10811-011-9712-1

Michalak I, Chojnacka K (2014) Algal extracts: Technology and advances. Eng Life Sci 14:581-591. doi: 10.1002/elsc.201400139

Miller IJ (2005) The structure of polysaccharides from selected New Zealand species of Grateloupia. Bot Mar 48:157-166. doi: 10.1515/BOT.2005.017

Munier M (2013) Pigmentary polymorphism study of the red algae Grateloupia turuturu through the purification and the characterization of R-Phycoerythrin in an industrial valorization context. Dissertation, University of Nantes

Munier M, Dumay J, Morançais M, et al (2013) Variation in the Biochemical Composition of the Edible Seaweed Grateloupia turuturu Yamada Harvested from Two Sampling Sites on the Brittany Coast (France): The Influence of Storage Method on the Extraction of the Seaweed Pigment RPhycoerythrin. J Chem 2013:1-8. doi: 10.1155/2013/568548

Munier M, Jubeau S, Wijaya A, et al (2014) Physicochemical factors affecting the stability of two pigments: R-phycoerythrin of Grateloupia turuturu and B-phycoerythrin of Porphyridium cruentum. Food Chem 150:400-407. doi: 10.1016/j.foodchem.2013.10.113

Özbek B, Ülgen KÖ (2000) The stability of enzymes after sonication. Process Biochem 35:1037-1043. doi: 10.1016/S0032-9592(00)00141-2

Peña-Farfal C, Moreda-Piñeiro A, Bermejo-Barrera A, et al (2005) Speeding up enzymatic hydrolysis procedures for the multi-element determination in edible seaweed. Anal Chim Acta 548:183-191. doi: 10.1016/j.aca.2005.06.004

Petit A-C, Noiret N, Guezennec J, et al (2007) Ultrasonic depolymerization of an exopolysaccharide produced by a bacterium isolated from a deep-sea hydrothermal vent polychaete annelid. Ultrason Sonochem 14:107-112. doi: 10.1016/j.ultsonch.2006.03.010

Pétrier C, Gondrexon N, Boldo P (2008) Ultrasons et sonochimie. Tech Ing Sci Fondam AFP4:15.

Romarís-Hortas V, Bermejo-Barrera P, Moreda-Piñeiro A (2013) Ultrasound-assisted enzymatic hydrolysis for iodinated amino acid extraction from edible seaweed before reversed-phase high performance liquid chromatography-inductively coupled plasma-mass spectrometry. J Chromatogr A 1309:33-40. doi: 10.1016/j.chroma.2013.08.022

Sørensen HR, Pedersen S, Meyer AS (2007) Synergistic enzyme mechanisms and effects of sequential enzyme additions on degradation of water insoluble wheat arabinoxylan. Enzyme Microb Technol 40:908-918. doi: 10.1016/j.enzmictec.2006.07.026

Sørensen HR, Pedersen S, Viks $\varnothing$-Nielsen A, Meyer AS (2005) Efficiencies of designed enzyme combinations in releasing arabinose and xylose from wheat arabinoxylan in an industrial ethanol fermentation residue. Enzyme Microb Technol 36:773-784. doi: 10.1016/j.enzmictec.2005.01.007

Souza M, Mezadri ET, Zimmerman E, et al (2013) Evaluation of activity of a commercial amylase under ultrasound-assisted irradiation. Ultrason Sonochem 20:89-94. doi: 10.1016/j.ultsonch.2012.05.012

Stiger-Pouvreau V, Thouzeau G (2015) Marine Species Introduced on the French Channel-Atlantic Coasts: A 
Review of Main Biological Invasions and Impacts. Open J Ecol 5:227-257. doi: 10.4236/oje.2015.55019

Subhedar PRGPB, Gogate PR (2013) Intensification of Enzymatic Hydrolysis of Lignocellulose Using Ultrasound for Efficient Bioethanol Production: A Review. Ind Amp Eng Chem Res 52:1181611828. doi: 10.1021/ie401286z

Sulaiman AZB, Ajit A, Yunus RBM, Chisti Y (2010) Effects of ultrasound on enzymatic hydrolysis of soluble cellulose. J Biotechnol 150, Supplement:135. doi: 10.1016/j.jbiotec.2010.08.354

Szabó OE, Csiszár E (2013) The effect of low-frequency ultrasound on the activity and efficiency of a commercial cellulase enzyme. Carbohydr Polym 98:1483-1489. doi: 10.1016/j.carbpol.2013.08.017

Toma M, Vinatoru M, Paniwnyk L, Mason TJ (2001) Investigation of the effects of ultrasound on vegetal tissues during solvent extraction. Ultrason Sonochem 8:137-142. doi: 10.1016/S13504177(00)00033-X

Vinatoru M, Toma M, Radu O, et al (1997) The use of ultrasound for the extraction of bioactive principles from plant materials. Ultrason Sonochem 4:135-139. doi: 10.1016/S1350-4177(97)83207-5

Wang F, Guo X-Y, Zhang D-N, et al (2015) Ultrasound-assisted extraction and purification of taurine from the red algae Porphyra yezoensis. Ultrason Sonochem 24:36-42. doi:

10.1016/j.ultsonch.2014.12.009

Wang T, Jónsdóttir R, Kristinsson HG, et al (2010) Enzyme-enhanced extraction of antioxidant ingredients from red algae Palmaria palmata. LWT - Food Sci Technol 43:1387-1393. doi: 10.1016/j.lwt.2010.05.010

Wijesinghe WAJP, Jeon Y-J (2012) Enzyme-assistant extraction (EAE) of bioactive components: A useful approach for recovery of industrially important metabolites from seaweeds: A review. Fitoterapia 83:6-12. doi: 10.1016/j.fitote.2011.10.016

Wong KH, Cheung PCK (2000) Nutritional evaluation of some subtropical red and green seaweeds: Part I proximate composition, amino acid profiles and some physico-chemical properties. Food Chem 71:475-482. doi: 10.1016/S0308-8146(00)00175-8

Wu H, Zhu J, Diao W, Wang C (2014) Ultrasound-assisted enzymatic extraction and antioxidant activity of polysaccharides from pumpkin (Cucurbita moschata). Carbohydr Polym 113:314-324. doi: 10.1016/j.carbpol.2014.07.025

Yachmenev V, Condon B, Klasson T, Lambert A (2009) Acceleration of the Enzymatic Hydrolysis of Corn Stover and Sugar Cane Bagasse Celluloses by Low Intensity Uniform Ultrasound. J Biobased Mater Bioenergy 3:25-31. doi: 10.1166/jbmb.2009.1002

Zhou C, Wang Y, Ma H, He R (2008) Effect of Ultrasonic Degradation on In Vitro Antioxidant Activity of Polysaccharides from Porphyra yezoensis (Rhodophyta). Food Sci Technol Int 14:479-486. doi: $10.1177 / 1082013208100665$ 


\section{Figure captions}

Fig. 1 Schematic representation of the ultrasound-assisted enzymatic hydrolysis (UAEH) process applied to a seaweed thallus. Formation of cavitation bubbles (a). Shearing forces created by bubble implosions near the seaweed surface (b). Seaweed compounds released towards the liquid phase and improved of enzyme access into the seaweed (c)

Fig. 2 Schematic diagram of the extraction system (a). Schematic illustration of the SONITUBE $^{\circledR}$, an ultrasonic flow-through reactor (SYNETUDE, France) (b)

Fig. 3 Evolution of the gain in seaweed liquefaction for each process (Control, enzyme-assisted extraction (EAE), ultrasound-assisted extraction (UAE) and ultrasound-assisted enzymatic hydrolysis (UAEH)) during $360 \mathrm{~min}$ at $40{ }^{\circ} \mathrm{C}$. Values are means \pm standard deviation, $\mathrm{n}=3$

Fig. 4 Percentage of solubilized material at $360 \mathrm{~min}$ for the Control, enzyme-assisted extraction (EAE), ultrasound-assisted extraction (UAE) and ultrasound-assisted enzymatic hydrolysis (UAEH), at $40{ }^{\circ} \mathrm{C}$. Values are means \pm standard deviation, $n=3$. Significant differences $(\mathrm{p}<0.05)$ are indicated by different letters

Fig. 5 Biochemical composition of soluble fractions at $360 \mathrm{~min}$ for the Control, enzyme-assisted extraction (EAE), ultrasound-assisted extraction (UAE) and ultrasound-assisted enzymatic hydrolysis (UAEH) at $40{ }^{\circ} \mathrm{C}$. Carbohydrates (a); Carbon (b) and Nitrogen (c). Values are means \pm standard deviation, $\mathrm{n}=3$ except for UAEH carbohydrates $(n=2)$. Significant differences $(p<0.05)$ are indicated by different letters. dw: dried weight

Fig. 6 Amino Acid (AA) profiles expressed as a percentage of the total AA detected for seaweed $(G$. turuturu) and soluble fractions at $40^{\circ} \mathrm{C}$ after $360 \mathrm{~min}$ (Control and ultrasound-assisted enzymatic hydrolysis (UAEH)). Classification into two categories: Essential Amino Acids (EAA) and Non-Essential Amino Acids (NEAA). Tryptophan, hydroxyproline and hydroxylysine were not detected. * Essential amino acid for children. Values are means \pm standard deviation, $n=2$

Fig. 7 Microscopic observations during the processes. Magnification 100 (a); Magnification 1,000 (b). A/B: Seaweed before processing; enzyme-assisted extraction (EAE), ultrasound-assisted extraction (UAE) and ultrasound-assisted enzymatic hydrolysis (UAEH) at $180 \mathrm{~min}(-1)$ and $360 \mathrm{~min}(-2)$. Arrows indicate examples of holes in the thallus 
Fig. 1 Schematic representation of the ultrasound-assisted enzymatic hydrolysis (UAEH) process applied to a seaweed thallus. Formation of cavitation bubbles (a). Shearing forces created by bubble implosions near the seaweed surface (b). Seaweed compounds released towards the liquid phase and improved of enzyme access into the seaweed $(\mathbf{c})$
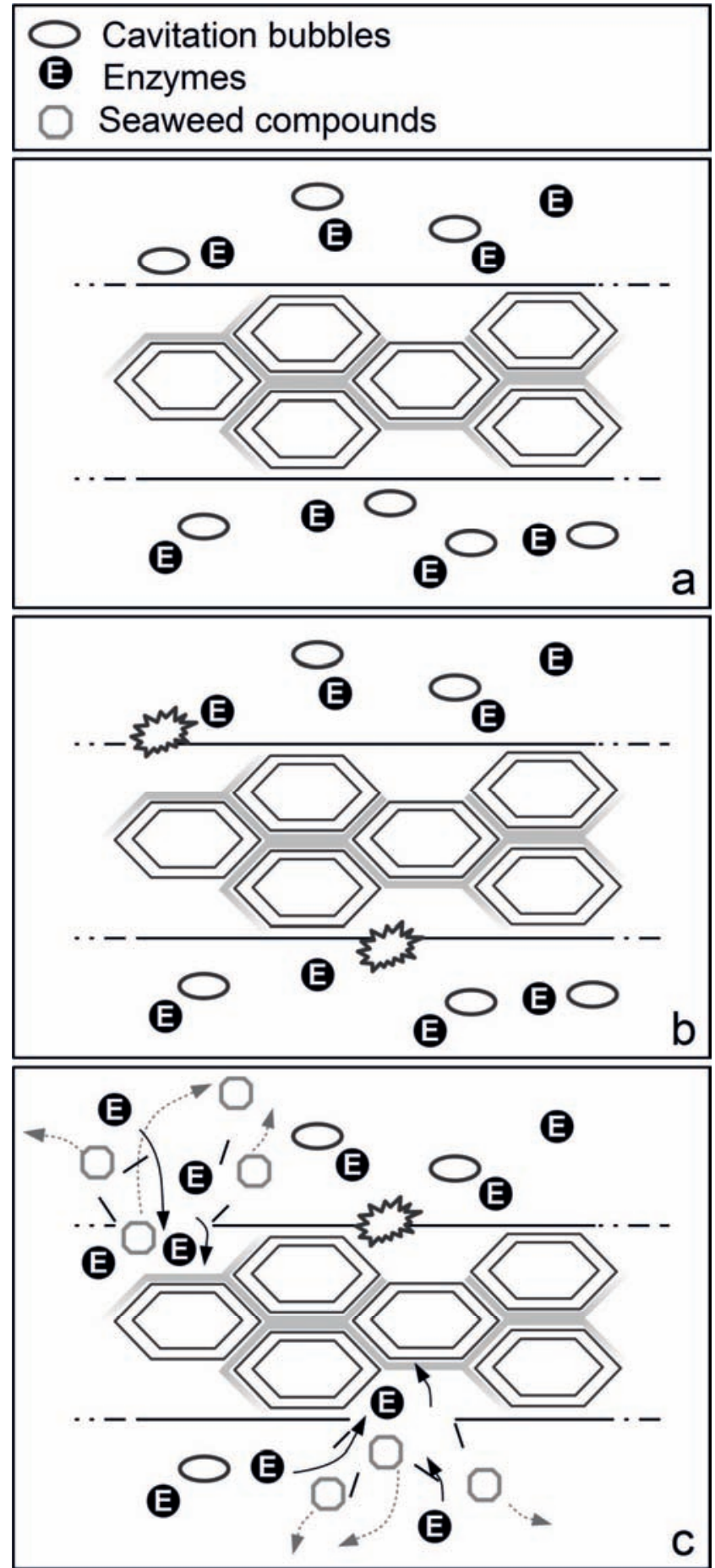
Fig. 2 Schematic diagram of the extraction system (a). Schematic illustration of the SONITUBE ${ }^{\circledR}$, an ultrasonic flow-through reactor (SYNETUDE, France) (b)
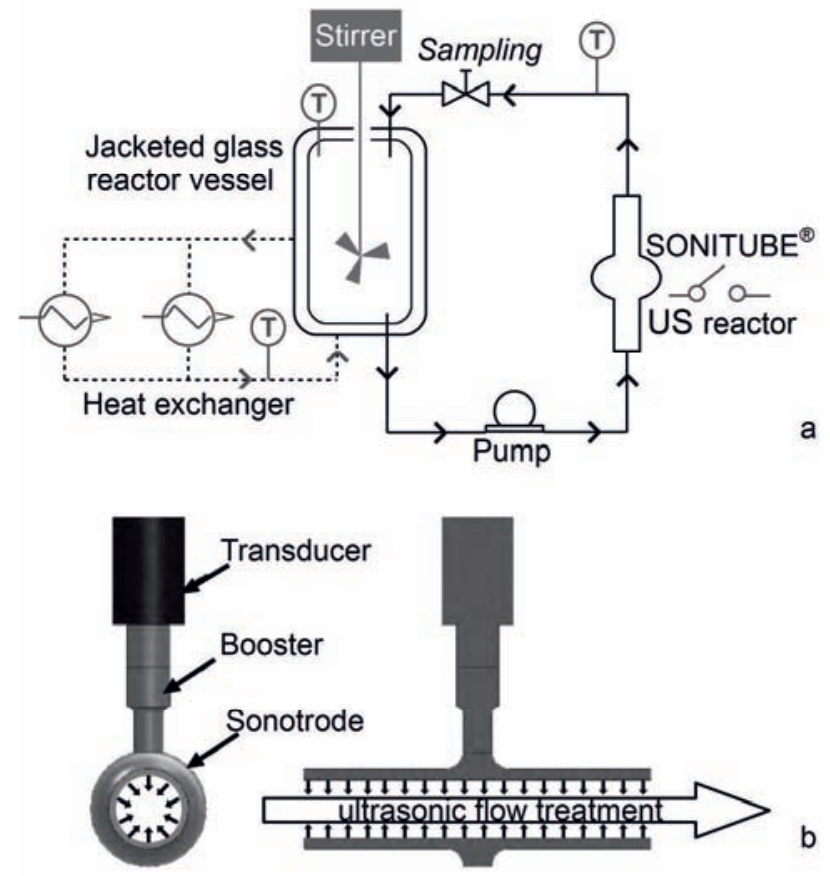
Fig. 3 Evolution of the gain in seaweed liquefaction for each process (Control, enzyme-assisted extraction (EAE), ultrasound-assisted extraction (UAE) and ultrasound-assisted enzymatic hydrolysis (UAEH)) during $360 \mathrm{~min}$ at $40{ }^{\circ} \mathrm{C}$. Values are means \pm standard deviation, $\mathrm{n}=3$

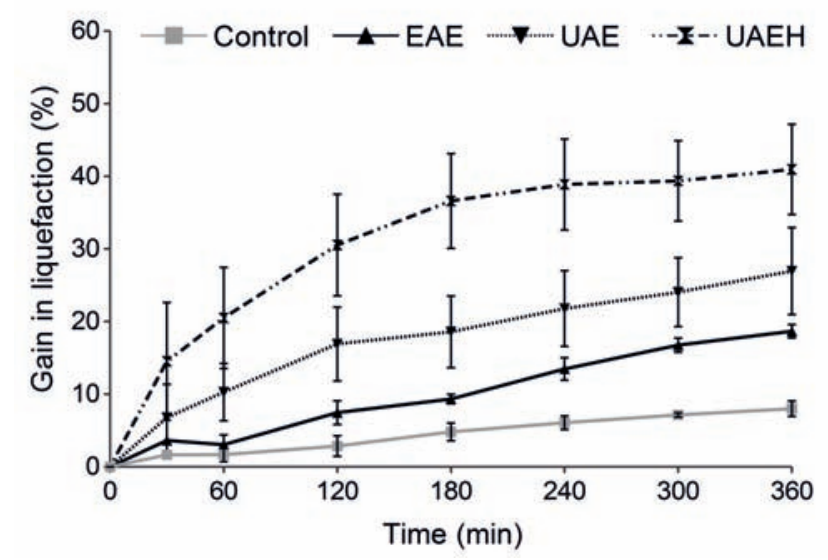


Fig. 4 Percentage of solubilized material at $360 \mathrm{~min}$ for the Control, enzyme-assisted extraction (EAE), ultrasound-assisted extraction (UAE) and ultrasound-assisted enzymatic hydrolysis (UAEH), at $40{ }^{\circ} \mathrm{C}$. Values are means \pm standard deviation, $n=3$. Significant differences $(\mathrm{p}<0.05)$ are indicated by different letters

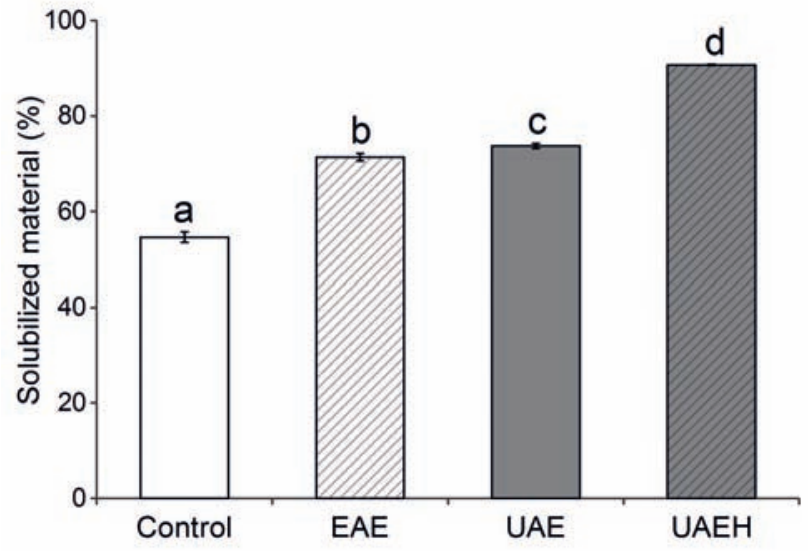


Fig. 5 Biochemical composition of soluble fractions at $360 \mathrm{~min}$ for the Control, enzyme-assisted extraction (EAE), ultrasound-assisted extraction (UAE) and ultrasound-assisted enzymatic hydrolysis (UAEH) at $40{ }^{\circ} \mathrm{C}$. Carbohydrates (a); Carbon (b) and Nitrogen (c). Values are means \pm standard deviation, $\mathrm{n}=3$ except for UAEH carbohydrates $(n=2)$. Significant differences $(p<0.05)$ are indicated by different letters. dw: dried weight
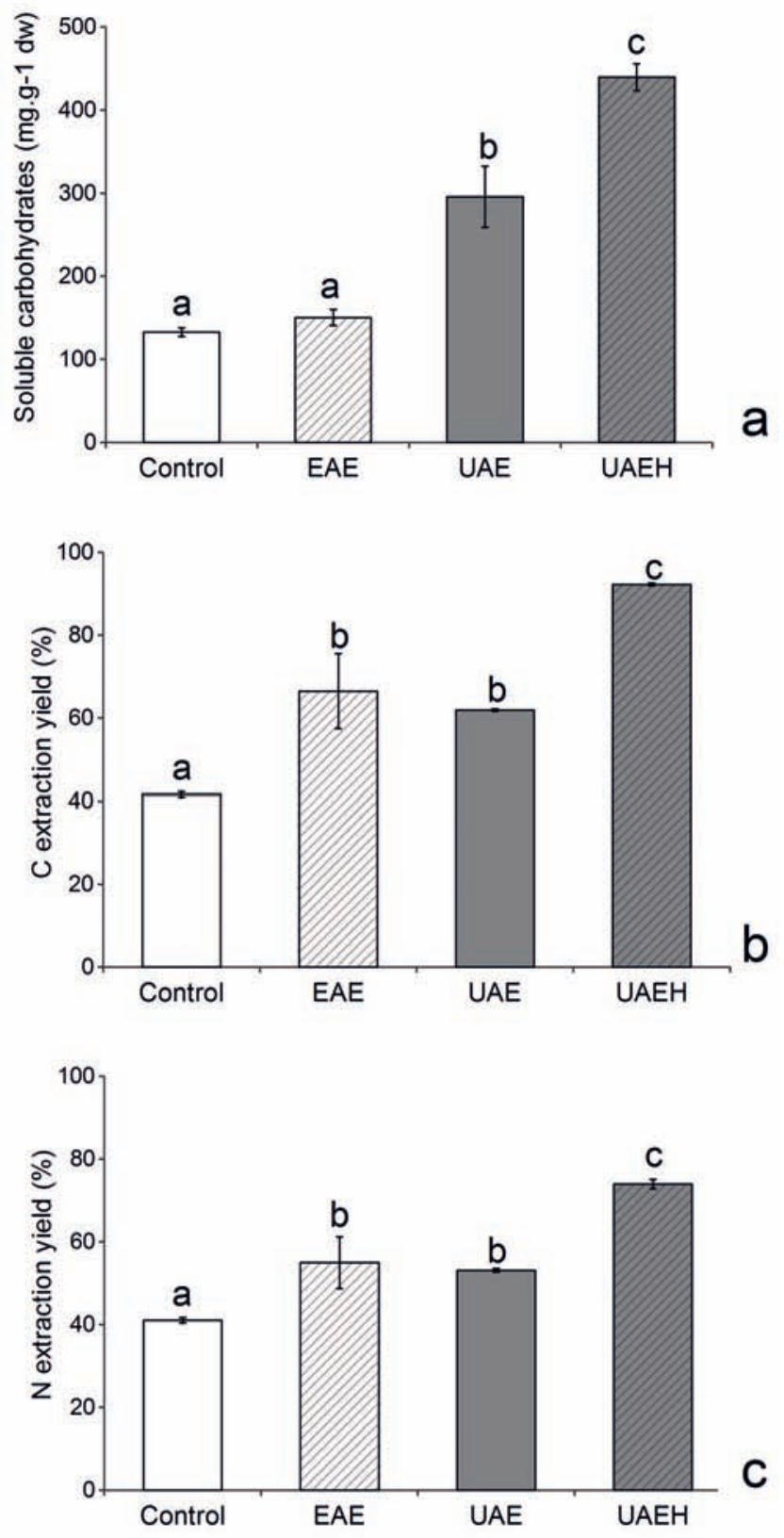
Fig. 6 Amino Acid (AA) profiles expressed as a percentage of the total AA detected for seaweed $(G$. turuturu) and soluble fractions at $40^{\circ} \mathrm{C}$ after $360 \mathrm{~min}$ (Control and ultrasound-assisted enzymatic hydrolysis (UAEH)). Classification into two categories: Essential Amino Acids (EAA) and Non-Essential Amino Acids (NEAA). Tryptophan, hydroxyproline and hydroxylysine were not detected. * Essential amino acid for children. Values are means \pm standard deviation, $n=2$

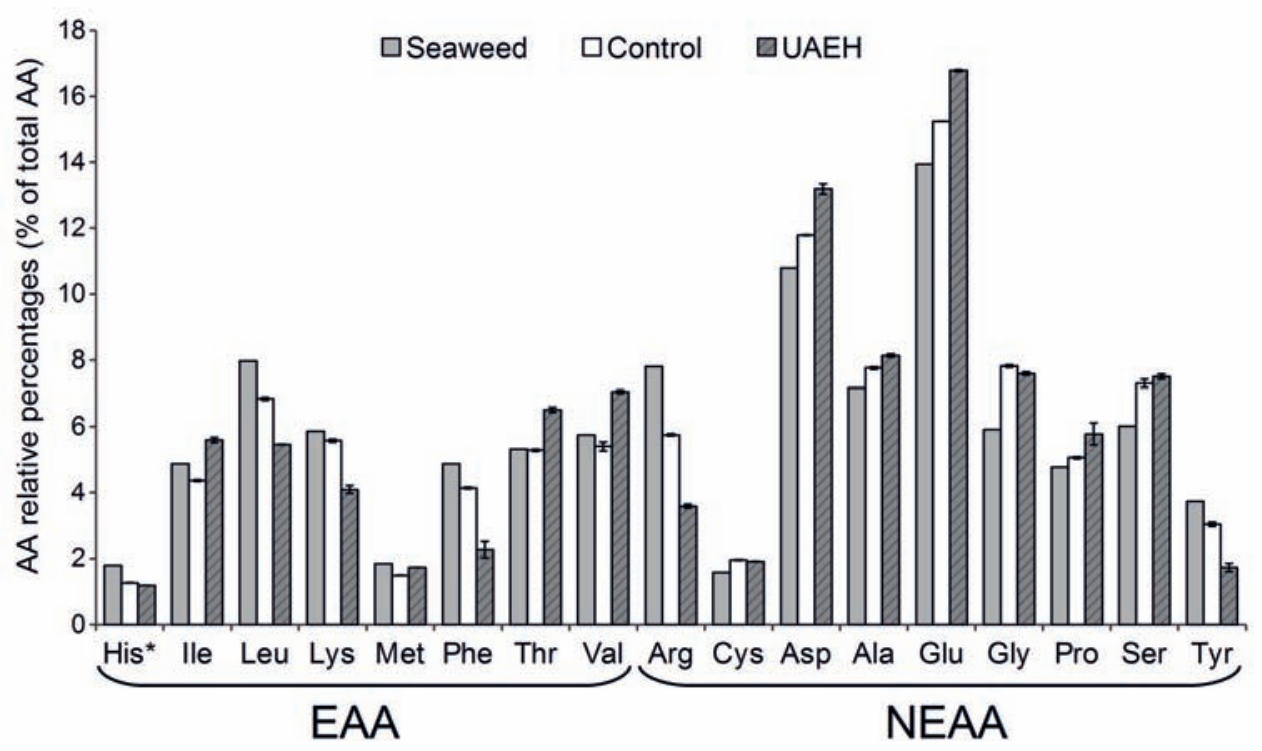


Fig. 7 Microscopic observations during the processes. Magnification 100 (a); Magnification 1,000 (b). A/B: Seaweed before processing; enzyme-assisted extraction (EAE), ultrasound-assisted extraction (UAE) and ultrasound-assisted enzymatic hydrolysis (UAEH) at $180 \mathrm{~min}(-1)$ and $360 \mathrm{~min}(-2)$. Arrows indicate examples of holes in the thallus

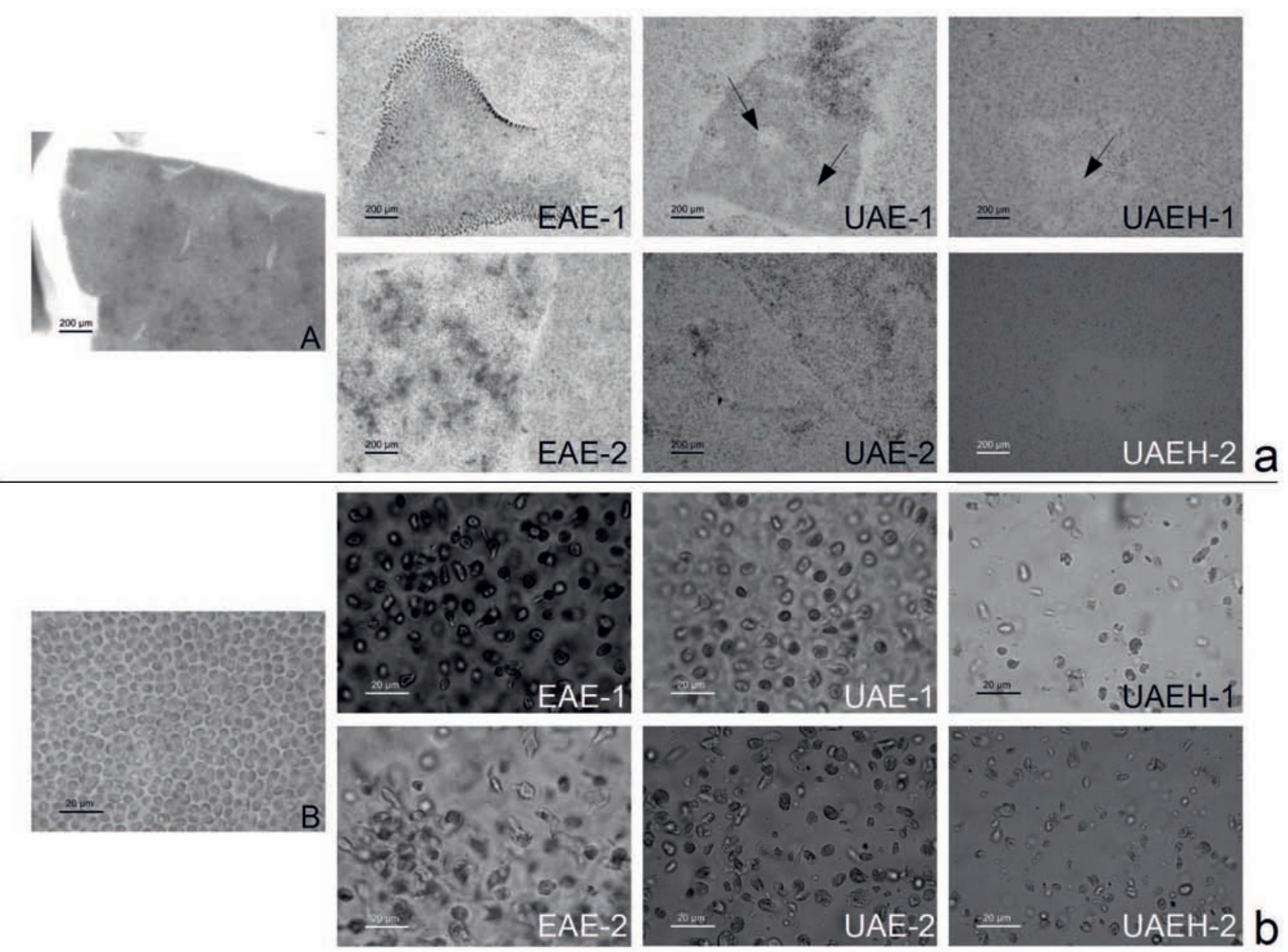




\section{Tables captions}

Table 1 Enzymatic cocktail composition: activities, $\mathrm{pH}$ and temperature ranges. Minimum (Min), maximum (Max) and optimal (Opt) values are given

Table 2 G. turuturu biochemical composition

Table 3 Quantitative analysis and extraction yields for G. turuturu, Control and ultrasound-assisted enzymatic hydrolysis (UAEH) after $360 \mathrm{~min}$ at $40{ }^{\circ} \mathrm{C}$ 


\section{Tables}

Table 1 Enzymatic cocktail composition: activities, $\mathrm{pH}$ and temperature ranges. Minimum (Min), maximum (Max) and optimal (Opt) values are given

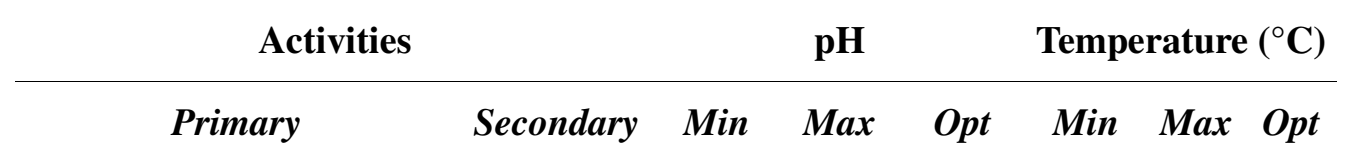

\begin{tabular}{|c|c|c|c|c|c|c|c|c|}
\hline Sumizyme TG & $\begin{array}{l}\text { B-1,3-glucanase } \\
\text { Botrytis glucanase }\end{array}$ & & 3.5 & 8 & 4 & 40 & 50 & 50 \\
\hline Sumizyme MC & Polygalacturonase & $\begin{array}{l}\text { Protease } \\
\text { Amylase }\end{array}$ & 5 & 6 & 5 & 40 & 45 & 45 \\
\hline Multifect $^{\circledR}$ CX 15L & $\begin{array}{c}\text { Cellulase } \\
\text { ß glucosidase }\end{array}$ & & 4 & 6 & 5 & 35 & 65 & 55 \\
\hline Ultraflo $^{\circledR} \mathbf{X L}$ & ß glucanase (endo-1,3(4-)) & $\begin{array}{l}\text { Xylanase } \\
\alpha \text { amylase }\end{array}$ & $\mathrm{Nd}^{*}$ & $\mathrm{Nd}^{*}$ & 6 & 40 & 65 & $\mathrm{Nd}^{*}$ \\
\hline
\end{tabular}

\footnotetext{
* Non defined values
} 
Table 2 G. turuturu biochemical composition

Grateloupia turuturu

\begin{tabular}{lr}
\hline Dry weight $(\%$ ww) & $14.17 \pm 0.10$ \\
\hline Ash $(\% \mathrm{dw})$ & $30.69 \pm 0.75$ \\
\hline Total NaCl $\% \mathrm{dw})$ & $16.77 \pm 0.90$ \\
\hline Total N (\% dw) & $3.62 \pm 0.07$ \\
\hline Total C (\% dw) & 18.44 \\
\hline Total amino acids $(\% \mathrm{dw}) *$ & $3.25 \pm 0.6$ \\
\hline Total lipids $(\% \mathrm{dw})$ & \\
\hline
\end{tabular}

Values are means \pm standard deviation, $n=3$. dw: dried weight, ww: wet weight. *Tryptophan, hydroxyproline and hydroxylysine were not detected, $n=1$ 
Table 3 Quantitative analysis and extraction yields for G. turuturu, Control and ultrasound-assisted enzymatic hydrolysis (UAEH) after $360 \mathrm{~min}$ at $40{ }^{\circ} \mathrm{C}$

\begin{tabular}{|c|c|c|c|c|c|}
\hline & & & & & \\
\hline & & & $\begin{array}{c}\mathbf{N} \text { content } \\
(\% \mathrm{dw})\end{array}$ & $\begin{array}{c}\text { C content } \\
(\% \mathrm{dw})\end{array}$ & $\begin{array}{c}\text { Total AA content } * \\
(\% \mathrm{dw})\end{array}$ \\
\hline \multicolumn{3}{|c|}{ G. turuturu (dried powder) } & $3.62 \pm 0.07$ & $29.11 \pm 0.53$ & 18.44 \\
\hline & $\begin{array}{c}\text { Solubilized } \\
\text { material }(\%)\end{array}$ & $\begin{array}{c}\text { Carbohydrates } \\
\text { content }\left(\mathrm{mg} \cdot \mathrm{g}^{-1} \mathrm{dw}\right)\end{array}$ & $\begin{array}{c}\mathbf{N} \text { extraction } \\
\text { yield }(\%)\end{array}$ & $\begin{array}{c}\text { C extraction } \\
\text { yield }(\%)\end{array}$ & $\begin{array}{c}\text { Total AA extraction } \\
\text { yield }(\%)\end{array}$ \\
\hline Control & $54.60 \pm 1.09$ & $132.90 \pm 5.15$ & $41.05 \pm 0.69$ & $41.58 \pm 0.69$ & $25.79 \pm 0.57$ \\
\hline UAEH & $90.71 \pm 0.13$ & $439.43 \pm 16.39$ & $73.95 \pm 1.16$ & $92.27 \pm 0.34$ & $54.06 \pm 0.19$ \\
\hline
\end{tabular}

Values are means \pm standard deviation, dw: dried weight. *Tryptophan, hydroxyproline and hydroxylysine were not detected 